\title{
AKTIVITAS ANTIBAKTERI EKSTRAK ETANOL KULIT BUAH PEPAYA MUDA (CARICCA PAPAYA L) TERHADAP ESCHERICHIA COLI DAN STAPHYLOCOCCUS AUREUS SECARA IN VITRO
}

\author{
Citra Trisna ${ }^{1}$, Mardyana Nizar $^{1}$ \\ Analis Kesehatan Politeknik Kesehatan Kemenkes Banten, Tangerang \\ Korespondensi: citratrisna75@gmail.com
}

\begin{abstract}
Infections caused by bacteria, require antibiotics for their treatment. The use of inappropriate antibiotics causes bacterial resistance. Several studies conducted research on plants that can be used to treat infectious diseases. From the research, many medicinal plants were used to cure infectious diseases. One of them is the papaya plant (Carica papaya L). The purpose of this study was to determine the active substance on the fruit skin of Carica papaya $L$ which functions as an antibacterial and to know the activity of ethanol extract of young papaya fruit skin (Carica papaya L) on E. coli and Staphylococcus aureus. This type of research is a laboratory experiment. The sample in this study was $3 \mathrm{~kg}$ of Carica papaya L. fruit peel. Ethanol extraction of Carica papaya L fruit peel was carried out to determine the content of secondary metabolites. Phytochemical tests were carried out to determine the antibacterial content in the samples, then tested the antibacterial activity against E. coli and Staphylococcus aureus, with concentrations of $25 \%, 50 \%, 75 \%$ and $100 \%$. Phytochemical test results obtained positive contents of the ceiling, saponins and steroids. In the antibacterial activity of $96 \%$ ethanol extract against E. coli no inhibition was found at all concentrations. The results of the antibacterial activity test on Stapylococcus aureus bacteria, the inhibition was obtained from a concentration of $25 \%$ of 0.55 $\mathrm{mm}$ the highest inhibition power at a concentration of $100 \%$ of $2.95 \mathrm{~mm}$.
\end{abstract}

\section{Keywords: Carica papaya $L$ papaya peel, phytochemical test, antibacterial}

\begin{abstract}
ABSTRAK
Penyakit infeksi yang disebabkan oleh bakteri, memerlukan antibiotika untuk pengobatannya. Pemakaian antibiotika yang tidak tepat menyebabkan terjadinya resistensi. Beberapa penelitian melakukan penelitian terhadap tanaman yang dapat digunakan untuk pengobatan penyakit infeksi. Dari penelitian didapatkan banyak tanaman obat yang digunakan untuk menyembuhkan penyakit infeksi. Salah satu diantaranya adalah tanaman pepaya (Carica papaya L). Tujuan penelitian ini adalah untuk mengetahui zat aktif pada kulit buah Carica papaya L yang berfungsi sebagai antibakteri dan mengetahui aktivitas ekstrak etanol kulit buah pepaya muda (Carica papaya L) terhadapa bakteri E. coli dan Staphylococcus aureus. Jenis penelitian ini adalah eksperimen laboratoratorium. Sampel pada penelitian ini sebanyak $3 \mathrm{~kg}$ kulit buah Carica papaya
\end{abstract}


L. Dilakukan ekstraksi etanol kulit buah Carica papaya L untuk mengetahui kandungan metabolit sekunder. Dilakukan uji fitokimia untuk mengetahui kandungan antibakteri pada sampel, selanjutnya dilakukan uji aktivitas antibakteri terhadap bakteri E. coli dan Staphylococcus aureus, dengan konsentrasi 25\%, 50\%, 75\% dan 100\%. Hasil uji fitokimia didapatkan kandungan positif plafonoid, saponin dan steroid. Pada uji aktivitas antibakteri ekstrak etanol 96\% terhadap E. coli tidak ditemukan daya hambat pada semua konsentrasi. Hasil uji aktivitas antibakteri terhadap bakteri Stapylococcus aureus, didapatkan daya hambat mulai dari konsentrasi $25 \%$ sebesar $0,55 \mathrm{~mm}$ daya hambat tertinggi pada konsentrasi $100 \%$ sebesar 2,95 $\mathrm{mm}$.

\section{Kata kunci: Kulit buah pepaya Carica papaya L, uji fitokimia, antibakteri}

\section{PENDAHULUAN}

Penyakit infeksi merupakan penyakit yang disebabkan oleh mikroba patogen (Darmadi, 2008). Salah satu mikroba patogen tersebut adalah bakteri. Pengobatan penyakit infeksi yang disebabkan bakteri ini diantaranya dengan pemberian antibiotik (Hare, 1993). Penggunaan antibiotik yang tidak tepat dapat menyebabkan berkembangnya bakteri-bakteri yang kebal terhadap obat (Green, 2005).

Berdasarkan hasil penelitian pola kepekaan kuman terhadap antibiotik di ruang rawat intensif RS. Fatmawati Jakarta tahun 2001-2002 oleh Refdanita et al (2004) pola kepekaannya menunjukan bahwa kuman patogen yang diteliti (Pseudomonas sp, Klebsiella sp, Escherichia coli, Streptococcus haemophiliticus, Staphylococcus epidermidis dan Staphylococcus aureus) mempunyai

Jurnal Medikes, Volume 5, Edisi 2, November 2018 resistensi tertinggi terhadap ampisilin, amoksisilin, penisilin G, tetrasiklin dan kloramfenikol. Hal ini terjadi permasalahan baru dalam dunia kesehatan oleh karena itu perlu dilakukan penelitian dan pengembangan obat antibakteri secara terus menerus untuk dapat mengatasi permasalahan bakteri yang resisten terhadap antibiotik.
Banyak tanaman obat yang menurut sejarah telah digunakan untuk menyembuhkan infeksi-infeksi yang disebabkan oleh bakteri yang sekarang telah resisten. Salah satu tanaman yang dapat dimanfaatkan sebagai obat tradisional adalah tanaman pepaya (Carica pepaya L). Seluruh bagian pepaya dari akar, daun, buah, kulit, getah memiliki nilai medis yang tinggi (Tietze, 2002).Pada dasarnya kandungan kulit pepaya kurang lebih sama dengan 
daging buahnya, Selain enzim papain, kulit pepaya juga mengandung alkaloid karpina, glukosid, saponin, sakrosa,dextrose.

Pada penelitian yang dilakukan oleh E.I. Okoye (2011) telah dilakukan uji aktivitas antibakteri dan antijamur dari ekstrak etanol dan ekstrak air. Diperoleh hasil bahwa biji pepaya muda yang berwarna putih memiliki aktivitas antibakteri terhadap Staphylococcus aureus, Pseudomona aeruginosa, Salmonella typhi, Escherichia coli dan anti jamur terhadap Aspergillus niger, Penicillium notatum, Fusarium solani, Candida albican. Oleh karena itu, akan dilakukan penelitian tentang Aktivitas Antibakteri Ekstrak Etanol Kulit Buah Pepaya Muda (Caricca papaya L) Terhadap Eschechia coli dan Staphylococcus aureus.

\section{METODE}

Penelitian ini merupakan penelitian eksperimental dengan uji laboratorium. Uji laboratorium dilakukan untuk mengetahui aktivitas antibakteri ekstrak etanol kulit buah pepaya muda terhadap bakteri E. coli dan Staphylococcus aureus. Waktu dan tempat penelitian dilaksanakan di laboratorium Mikrobiologi Jurusan Analis Kesehatan Poltekkes Kemenkes Banten dan Biofarmaka IPB, waktu penelitian pada September-
Oktober 2017. Sampel yang digunakan adalah kulit buah papaya muda sebanyak 3 kg. Kulit buah papaya muda dikeringkan dalam oven pada suhu 37-40 C selama 4-5 jam. Kulit buah pepaya muda kering kemudian dihaluskan menjadi serbuk, hasil yang diperoleh digunakan sebagai sampel. Selanjutnya dibuat Ekstraksi Etanol Kulit Buah Pepaya Muda dengan cara Serbuk kering kulit buah pepaya muda sebanyak 200 g ditambahkan Ethanol p.a $2000 \mathrm{ml}$ kemudian dilakukan proses ekstraksi dengan metode maserasi (pengadukan 1 jam, pendiaman 2x24 jam). Hasilnya di saring dan diperoleh filtrat. Filtrat kemudian dipekatkan dengan rotary evaporator sampai didapatkan ekstrak kental.

Dilakukan pengujian kualitatif komponen kimia/ Uji Fitokimia berupa: Uji Alkaloid, Uji Terpenoid dan Steroid, Uji Flavonoid, dan Uji Saponin. Untuk mengetahui kandungan kimia yang terdapat dalam kulit buah papaya muda. Selanjutnya dilakukan Uji Daya Hambat Bakteri. Uji daya hambat bakteri dilakukan dengan cara: (1) Media Nutrien Agar (NA) dibuat dan dimasukan ke dalam cawan petri2, (2) Dibiarkan medium memadat sekitar 5 menit, (3) Dipipet $50 \mu \mathrm{L}$ suspensi bakteri E.coli dan Staphylococcus aureu, (4) Diteteskan diatas 
media Nutrien Agar (NA), (5) Disebar suspensi bakteri pada seluruh permukaan lempengan agar. Untuk mendapatkan pertumbuhan yang merata gores secara mendatar dengan menggunakan swab steril, (6) Kertas cakram yang telah ditetesi ekstrak etanol kulit buah pepaya muda dengan konsentrasi 25\%, 50\%, 75\% dan 100\% diletakkan di atas permukaan media bakteri dengan pinset dan di tekan sedikit, (7) Sebagai kontrol positif digunakan tetrasiklin 1000 ppm, (8) Sebagai kontrol negatif digunakan kertas cakram ditetesi DMSO, (9) Diinkubasi selama 24 jam pada suhu $37^{\circ} \mathrm{C}$, (10) Diameter zona hambat yang terbentuk diukur dengan penggaris dan dinyatakan dalam millimeter.

\section{HASIL DAN PEMBAHASAN}

Analisis fitokimia yang dilakukan meliputi berbagai uji keberadaan metabolit sekunder seperti alkaloid, tanin, flavonoid, saponin, steroid, dan triterpenoid. Hasil uji fitokimia ekstak etanol kulit buah Carica papaya $L$ dapat dilihat pada Tabel 1 . Hasil uji fitokimia menunjukkan bahwa ekstrak etanol kulit buah Carica papaya $L$ mengandung komponen-komponen yang berfungsi sebagai antibakteri.
Tabel 1. Hasil uji fitokimia

\begin{tabular}{cl}
\hline Metabolit Sekunder & Hasil \\
\hline Flavonoid & + \\
Alkaloid & - \\
Tanin & - \\
Saponin & + \\
Quinon & - \\
Steroid & + \\
Triterpenoid & - \\
\hline
\end{tabular}

Pada tabel 1 terlihat bahwa kulit buah Carica papaya $L$ mengandung flavonoid, saponin dan steroid. Selanjutnya dilakukan uji aktivitas antibakteri terhadapa bakteri $E$. coli dan Staphylococcus aureus.

Pengukuran aktivitas antibakeri pada ekstrak etanol kulit buah Carica papaya $L$ terhadap E. coli dan Stapylococcus aureus, dengan kontrol positif tetrasiklin dan kontrol negatif Dimethyl Sufoxide (DMSO). Hasil aktivitas antibakteri dapat dilihat pada gambar 1.

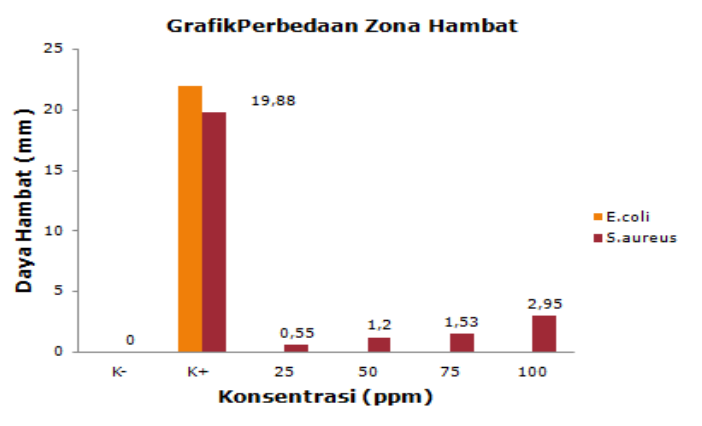

Gb 1. Aktivitas Antibakteri

Pada gambar 1 dapat dilihat bahwa pengujian aktivitas antibakteri ektrak etanol 
dengan menggunakan kulit buah pepaya muda (Carica papaya L) sebagai antibakteri E. coli pada konsentrasi 25 sampai $100 \%$ didapatkan hasil zona bening $6 \mathrm{~mm}$ dengan diameter cakram $6 \mathrm{~mm}$, artinya tidak terdapat daya hambat terhadap bakteri E. coli. Pengujian aktivitas antibakteri dengan sampel yang sama pada antibakteri Stapylococcus aeureus didapatkan diameter zona bening mulai dari konsentrasi $25 \%$ sampai dengan konsentrasi 100\%. Zona bening pada konsentrasi $25 \%$ sebesar 0,55, diameter zona bening tertinggi $8,95 \mathrm{~mm}$ pada konsentrasi 100\%. Sebagai kontrol positif digunakan tetrasiklin. Uji aktivitas antibakteri dengan tetrasiklin 1000 ppm sebagai kontrol positif didapatkan diameter zona bening untuk E.coli sebesar 27,97 $\mathrm{mm}$ dan Stapylococcus aeureus sebesar 25,88 mm. Pengujian dengan Dymethyl sufoxid (DMSO) sebagai kontrol negatif didapatkan hasil zona bening $6 \mathrm{~mm}$ untuk uji aktivitas antibakteri E.coli dan Stapylococcus auereus, artinya tidak terdapat daya hambat bakteri pada DMSO.

Pada penelitian ini digunakan ekstraksi etanol kulit buah papaya muda (Carica papaya L). Tahapan ekstraksi merupakan tahapan penting untuk mengidentifikasi bioaktif yang terdapat

Jurnal Medikes, Volume 5, Edisi 2, November 2018 dalam sampel kulit buah Carica papaya L. Ekstraksi dilakukan menggunakan etanol 96\% sebanayk 2 L dengan metode maserasi. Pelarut ini dipilih karena kemampuannya dalam menarik komponen-komponen yang ada pada sampel sangat kuat sehingga dapat menarik seluruh senyawa metabolit sekunder dari mulai senyawa polar hingga non polar (Suwendiyanti, 2014).

Prinsip maserasi didasarkan pada kontak langsung antara pelarut dan bahan, pelarut akan masuk ke dalam matriks bahan melalui kapiler-kapiler dan melarutkan ekstrak karena adanya perbedaan konsentrasi antara larutan di dalam dan luar sel (proses difusi). Metode ini sederhana dan tidak merusak senyawa yang tidak tahan panas. Senyawa yang terbawa pada proses ekstraksi adalah senyawa yang mempunyai polaritas sesuai dengan pelarutnya. Perlakuan agitasi dilakukan untuk meningkatkan efek mekanis yang akan meningkatkan perpindahan massa dan interaksi antara pelarut dan bahan. Hal ini dapat memfasilitasi ekstraksi dengan meningkatkan difusi dan melepaskan larutan pekat dari permukaan sampel agar proses difusi berlanjut hingga tercapai keseimbangan konsentrasi larutan di dalam dan luar sel (Imelda 2013). 
Selanjutnya Uji kualitatif fitokimia bertujuan mengetahui kandungan senyawa metabolit sekunder pada kulit buah Carica papaya L. Hasil uji fitokimia yang dilakukan pada pelarut yang berbeda akan menunjukkan hasil yang berbeda dalam kekuatan sinyal yang diidentifikasi, yaitu tingkat kepekatan yang berbeda pada setiap pelarut (Egwaikhide \& Gimba 2007). Hasil uji fitokimia pada ekstrak etanol kulit buah Carica papaya $L$ dapat dilihat pada tabel 1 menunjukkan bahwa positif terhadap flavonoid, saponin, dan steroid. Flavonoid ditandai dengan adanya warna merah, kuning, dan jingga pada lapisan amil alkohol, steroid ditandai dengan warna hijau sedangkan saponin positif jika terbentuk buih yang stabil pada ekstrak.

Flavonoid merupakan golongan terbesar dari fenol dan terdapat dalam bentuk aglikon maupun glikosida dalam tanaman. Flavonoid berperan penting dalam biokimia dan fisiologi tanaman baik sebagai antioksidan, inhibitor enzim dan prekursor bagi komponen toksik. Flavonoid memiliki peranan sebagai antimikroba dan antivirus (Zulaicha 2011). Metabolit sekunder yang di sekresikan oleh tumbuhan seperti flavonoid, saponin dan steroid memiliki peran yang beragam.

Jurnal Medikes, Volume 5, Edisi 2, November 2018
Dalam penelitian ini diketahui bahwa ekstrak kulit buah Carica papaya $L$ tidak dapat menghambat pertumbuhan bakteri $E$. coli. Penelitian Niken (2014) dengan menggunakan ekstrak etanol biji pepaya mendapatkan hasil yang berbeda. Hasil yang didapatkan oleh Niken (2014), ekstrak etanol biji pepaya pada konsentrasi $50 \%$ dan $75 \%$ mempunyai daya hambat terhadap bakteri $E$. coli. Perbedaan hasil ini bisa disebabkan karena bagian pepaya yang diambil berbeda, sehingga kandungan zat antibakteri didalamnya juga berbeda.

Pengujian kandungan fitokimia pada tanaman yang sama dapat memberikan hasil yang berbeda. Pengujian terhadap bagian yang berbeda dalam tanaman yang sama juga memungkinkan terjadinya perbedaan. Hal ini karena kandungan fitokimia dapat dipengaruhi oleh beberapa hal seperti lingkungan tempat tumbuh termasuk perbedaan varietas dan kondisi geografis tempat tumbuh (Kardono 2003). Metode yang digunakan dalam ekstraksi, reagenreagen, dan kesensitifan alat juga menjadi penentu metabolit sekunder yang dihasilkan. Penggunaan pelarut yang berbeda dalam proses ekstraksi juga menentukan jenis metabolit sekunder yang terekstrak (Salim 2006). 
Penelitian Maria Tuntun (2016) Uji efektivitas Ekstrak daun pepaya terhadap bakteri E.coli dan Staphylococcus aureus didapatkan hasil konsentrasi $10 \%$ belum dapat menghambat pertumbuhan bakteri Escherichia, sedangkan pada konsentrasi $20 \%$ sampai $100 \%$ mampu menghambat pertumbuhan bakteri Escherichia coli. Terhadap bakteri Staphylococcus aureus, ekstrak daun pepaya konsentrasi $10 \%$ dan 20 $\%$ belum dapat menghambat pertumbuhan bakteri Staphylococcus aureus, sedangkan pada konsentrasi 30\% sampai 100\% mampu menghambat pertumbuhan bakteri Staphylococcus aureus. Hasil penelitian Oladimeji (2007) yang mendapatkan zona hambat pertumbuhan bakteri Escherichia coli sebesar $10 \mathrm{~mm}$ pada konsentrasi ekstrak daun pepaya $1,5 \%$ dan $11 \mathrm{~mm}$ pada konsentrasi ekstrak daun pepaya 3\%. Dan mendapatkan zona hambat pertumbuhan bakteri Staphylococcus aureus sebesar $13 \mathrm{~mm}$ pada konsentrasi ekstrak daun pepaya 1,5\% dan 15 mm pada konsentrasi ekstrak daun pepaya 3\%. Perbedaan ini dapat disebabkan karena beberapa hal, seperti perbedaan varietas daun pepaya, dan metode ekstraksi yang digunakan (Soranta, 2009).

Perbedaan daya hambat bakteri terhadap E. coli dan Staphylococcus

Jurnal Medikes, Volume 5, Edisi 2, November 2018 disebabkan oleh jenis kumannya yang berbeda. E. coli merupakan kuman gram positif, sedangkan Staphylococcus aureus merupakan kuman gram negatif. Hasil yang berbeda ini disebabkan karena ada perbedaan struktur kedua dinding bakteri, dimana bakteri gram negatif mempunyai struktur dinding sellebih kompleks dibanding gram negatif. Hal ini akan menyebabkan antibakteri lebih sukar masuk ke dalam sel untuk menghambat bakteri tersebut (Siswandono, 2000).

\section{SIMPULAN}

Analisis kualitatif yang dilakukan pada ekstrak etanol kulit buah Carica papaya $L$ menunjukkan bahwa mengandung senyawa flavonoid, saponin, dan steroid. Perlu dipertimbangkan pemanfaatan kulit buah pepaya karena adanya kandungan senyawa flavonoid, saponin dan steroid yang bagus untuk kesehatan. Analisis kuantitatif pada aktivitas antibakteri menunjukkan tidak terdapat daya hambat ekstrak terhadap bakteri E. coli. Terdapat daya hambat ekstrak pada Stapylococcus aureus mulai pada konsentrasi terendah yaitu $25 \%$ sebesar 0,55 $\mathrm{mm}$. Daya hambat meningkat sebanding dengan peningkatan konsentrasi, daya 
hambat paling tinggi didapatkan pada konsentrasi $100 \%$ yaitu sebesar 2,95. Dari penelitian ini dapat disimpulkan bahwa terdapat daya hambat ekstrak etanol kulit buah papaya carica $L$ pada bakteri pada Staphylococcus aureus, sebaliknya tidak terdapat daya hambat bakteri pada E. coli.

\section{DAFTAR PUSTAKA}

Darmadi. 2008. Infeksi Nasokomial, Problematika dan Pengendaliannya. Jakart. Penerbit Salemba Medika.

Egwaikhide \& Gimba.2007. Analysis of the Phytochemical Content and AntiMicrobial Actifity of Plectrantus Glandulosis Whole Plant. Middle of East Journal of Scientific Research

Green. 2005.Health Program Planning. An Educational Ecological Approach.New York.The MeGrawHill Companies, Inc

Hare. 1993. Mikrobiologi dan Imunologi.Diterjemahkan oleh Prasero. Penerbit. Yayasan Essentia Medica. Yogya

Imelda. 2013. Peranan Garlic pada Pengelolaan Hipertensi. CDK-209.

Okoye. 2011. Pleriminary Phytochemical Analysis and Antimicrobial Activity of Seeds of Carica papaya. Journal of Basic Physical Research

Paramesti N. 2014. Efektifitas Ekstrak Biji Pepaya (Carica Papaya L) Sebagai Antibakteri terhadap Bakteri

Jurnal Medikes, Volume 5, Edisi 2, November 2018
Eschericia coli. Skripsi. Universitas Islam NegeriHidayatullah. Jakarta

Refdanita. 2004. Pola Kepekaan Kuman terhadap Antibiotik di Ruang Rawat Intensif Rumah Sakit Fatmawati Jakarta Tahun 2001-2002. Jakarta: Makara Kesehatan. Vol 8 No 2

Salim A. 2006.Potensi Rebusan Daun Sirih Merah (Piper cratum)Sebagai senyawa Antihiperglikemia pada Tikus Galur Sparaguedawley.(Skripsi). Bogor: Fakultas Matematika dan Ilmu Pengetahuan Alam, Institut Pertanian Bogor

Tuntun Maria. 2016. Uji Efektivitas Ekstrak Daun Pepaya (Carica papaya L) terhadap Pertumbuhan Bakteri Escherichia coli dan Staphylococcus aureus. Jurnal Kesehatan Poltekkes Tanjungkarang. Vol. VII. No. 3. November 2016

Tietze. 2002. Terapi Pepaya. Jakarta:Prestasi Pustaka Publisher

Suwendiyanti. 2014. Efektifitas Ekstrak Akar, Batang, Kulit, Daun dan Fraksia Vicennia Marina sebagai Antioksidan (Skripsi) Universitas Padjajaran

Siswandono.2000. Kimia Medisinal. Airlangga. University Press Surabaya Soronta. 2009. Akativitas Antbakteri Ekstrak Etanol Daun Pepaya (Carica Papaya L) terhadap Eschericia coli dan Staphylococcus aureus Multiresisten Antibiotik. Skripsi. Universitas Muhammadiyah Surakarta

Zulaicha. 2011. Penggunaan Ekstrak Daun Sirsak (Annona Muricata Linn) Sebagai Pengendali Jamur Fusarium oxyporum Secara invitro. Skripsi. Surabaya. 